University of Thi-Qar Journal Vol.14 No.1 Mar 2019

Web Site: https://jutq.utq.edu.iq/index.php/main

Email: journal@jutq.utq.edu.iq

Microstructural Investigation of Wire Failure in

Wire Drawing Process

Fadhil A.Hashim, Sadiq M.Ihmood, Khalid A. Mohammed Engineering College, University of Thi-Qar https://doi.org/10.32792/utq/utj/vol14/1/5

Ghaffar Alwan Mohsin

Chief Mechanical Engineering-Manager of Power Cable Factory Ur S.C.E.I.

\title{
Email: sadiqmuhsin@yahoo.com
}

\section{Abstract}

This investigation concern to explain the failure operation that connected with wire drawing process. Microstructural examination was carried out for several samples of drawn wires. Copper and aluminum wires were pulled from $8 \mathrm{~mm}$ diameter to $3.5 \mathrm{~mm}$ for aluminum and to $1.75 \mathrm{~mm}$ for copper. The cross-sectional microstructure shows some porosity at the normal drawing condition, while no porosity at the drawing direction surface. The conclusion of this work represents that porosity will be created due to heat results from drawing process, which equal to recrystallization temperature or more, and accumulated porosity will be progressive to the final stage of wire failure.

Keywords: Wire failure, Wire drawing process, Microstructure of wire.

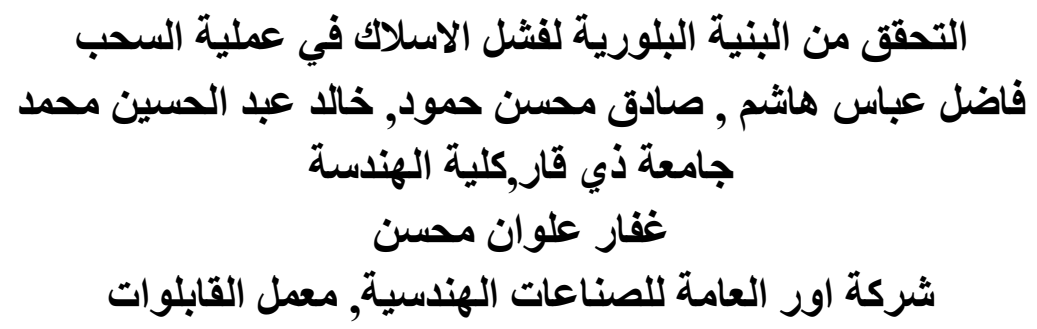

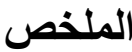

هذه الدراسة تضمنت توضيح عملية الانهيار التي تصاحب عمليات سحب الأسلاك. البنية

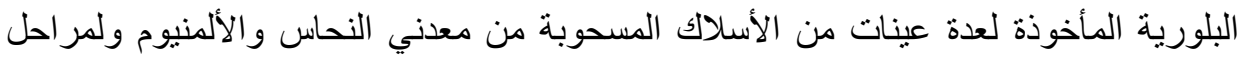




\section{University of Thi-Qar Journal Vol.14 No.1 Mar 2019 \\ Web Site: https://jutq.utq.edu.iq/index.php/main}

Email: journal@jutq.utq.edu.iq

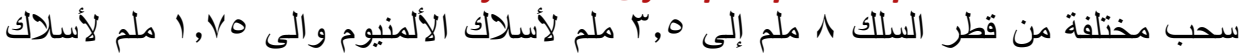

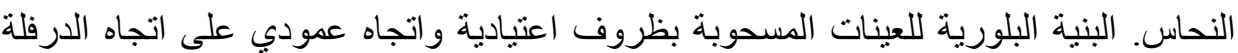

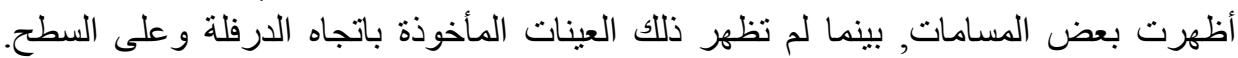

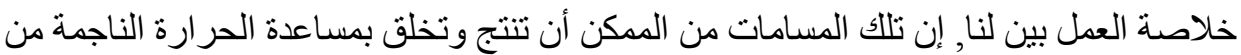

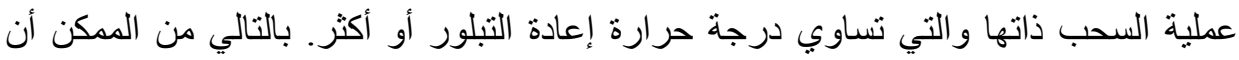
تتجمع ويؤدي ذلك إلى فثل السلك المسحوب.

\section{Introduction}

In the drawing process, the cross-sectional area and/or the shape of the rod, bar, tube, or wire is reduced by pulling through a die. One of the oldest metal-forming operations, drawing allows excellent surface finishes and closely controlled dimensions to be obtained in long products that have constants cross sections. Drawing is usually conducted at room temperature using a number of passes or reductions through consecutively located dies. An important exception is the warm drawing of tungsten to make incandescent lamp filaments. Annealing may occasionally be necessary after a number of drawing passes before the drawing operation is continued. The deformation is accomplished by a combination of tensile and compressive stresses that are created by the pulling force at the exit from the die and by the die configuration[1].

It is fundamental that the pulling force, or drawing stress, cannot exceed the strength of the wire drawn (otherwise, fracture or unstable deformation would occur). In fact, practical considerations often limit the drawing stress to about $60 \%$ of the as-drawn flow stress. Therefore, the area reduction per drawing pass is rarely greater than 30 to $35 \%$ [1].

When a metal is cold worked and plastically deformed, for instance, cold rolling or drawing, numerous dislocations are generated. These dislocations can interact with each other and form dislocations tangles. Such dislocation tangles hinder the movement of newly generated dislocations and, hence, further plastic deformation of the metal. In this way, a metal is strengthed or hardened by cold working. This strengthening mechanism is called work hardening[2]. Most of the energy expended in work hardening appears in the form of heat out, as shown in figure 1 , a finite fraction is stored in the material as strain energy[3]. When a work-hardened material is annealed, the deformed 


\section{University of Thi-Qar Journal Vol.14 No.1 Mar 2019 \\ Web Site: https://jutq.utq.edu.iq/index.php/main \\ Email: journal@jutq.utq.edu.iq}

grains in the material tend to recrystallize by forming fresh, strain-free grains that are soft, just like grains that have not been deformed. The stored strain energy is the driving force for recrystallization of a workhardened material[4], and this energy is released as fresh, strain-free grains form. Figure 2 shows the various stages of recrystallization in a work-hardened brass[5]. Slip bands, which have formed during severe work hardening serve as the nucleation sites for new grains. Before recrystallization takes place, there exists a period of time during which certain proportion of the work-hardened material, for instance, the electrical resistivity, tend to recover without causing any microstructural changes. This phenomenon is called recovery. However, since the mechanical proportion of the material, such as strength or hardness, do not change significantly during recovery, recovery is important in drawing[2].

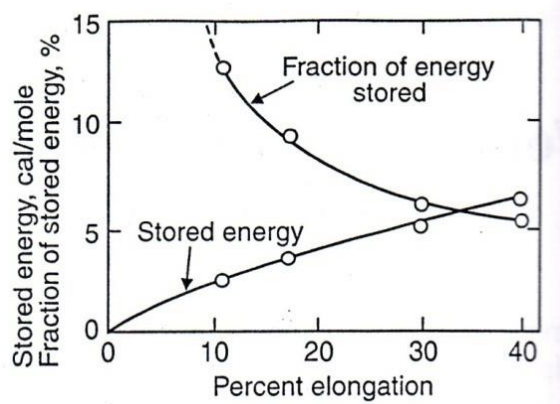

Figure 1 Stored energy and fraction of stored energy as a function oftensile elongation during cold working of high-purity copper 
Web Site: https://jutq.utq.edu.iq/index.php/main

Email: journal@jutq.utq.edu.iq

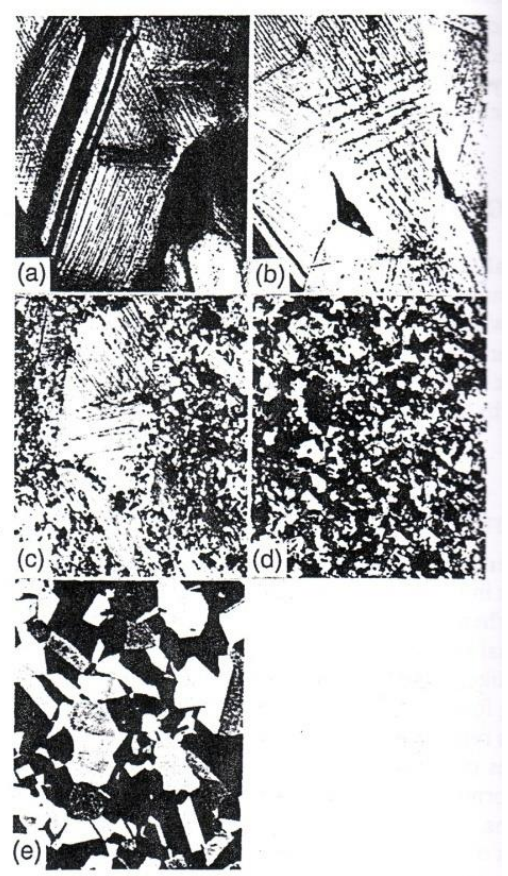

Figure 2 Deformation and recrystallization structures of $\alpha$-brass:(a) 33\% cold reduction; (b) short anneal at $580^{\circ} \mathrm{C}$; (c) longer anneal; (d) completely recrystallized; (e) grain growth.

\section{Experimental Work}

The drawing samples were taken from three drawing stages. These samples are from two metals, aluminum and copper. The raw wires is of $8 \mathrm{~mm}$ diameter. Through the drawing stages, the diameter will be $5 \mathrm{~mm}$ and finally $1.75 \mathrm{~mm}$ for copper wire, and $3.5 \mathrm{~mm}$ to $3 \mathrm{~mm}$ for aluminum wire. Microstructural testing were carried out for the different six samples, [8,3.5, and $3 \mathrm{~mm}$ for aluminum, 8,5, and $1.75 \mathrm{~mm}$ for copper], at the surface of rolling direction in second, [6 samples in rolling direction, and, 6 samples in perpendicular direction for two materials ]. Also is carried out for failure sample in two previous directions, for copper wire only. Samples were prepared for optical microscopy by grinding and polishing process. Photographs were taken for nonetched and etched samples. Etching solution was $\mathrm{FeCl}_{3}$ for copper samples, and, nital (2 $\mathrm{ml} \mathrm{HNO}_{3}, 98 \mathrm{ml}$ ethylalcohol) for aluminum samples. 


\section{University of Thi-Qar Journal Vol.14 No.1 Mar 2019 \\ Web Site: https://jutq.utq.edu.iq/index.php/main \\ Email: journal@jutq.utq.edu.iq}

\section{Results and Discussion}

Through rolling stages, the temperature of these wires increased to about recrystallization temperature $\left(250^{\circ} \mathrm{C}\right.$ for copper and $150^{\circ} \mathrm{C}$ for aluminum ). Grain growth cannot be happened because of the rolling process time is so small to allow this process to complete. Rolling stages is help defects accumulation, and push these defects in the drawing direction, one of these effective defects is porosity. When the volume of these accumulated porosity increases than the wire diameter, failure will happen. Figure 3 point out that all microstructures show almost porosity at the cross-section of the normal drawing samples. In fact porosity may welded by rolling force, while drawing heat, and recrystallization structure will help to creat another porosity (grain boundaries may cut the porosity creation ). Figure 4, explain the microstructure of the outer surface of the drawing direction samples, for different rolling stages, which shows clearly no porosity, which means that porosity is existing at the wire core only. Porosity at the surface may be disappear by welding process[ due to drawing stresses ], while that at the core of wires will sustain these stresses, and may at any time of drawing will growing up, and then its volume will be effective to decrease the wire strength, and failure may happen at the final drawing stage. Figure 5 and 6 point out the porosity accumulation at the surface and core of failure wire, which means that porosity defect is the main reason for wire failure at the wire drawing process. 
University of Thi-Qar Journal Vol.14 No.1 Mar 2019

Web Site: https://jutq.utq.edu.iq/index.php/main

Email: journal@jutq.utq.edu.iq

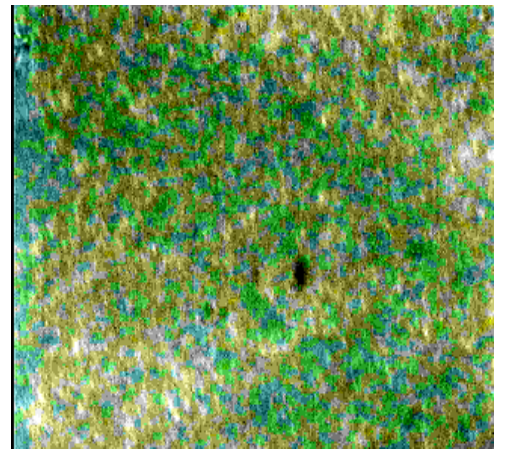

(a)

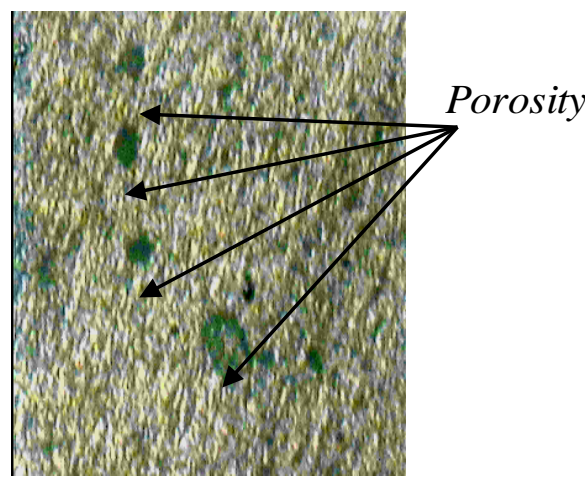

(c)

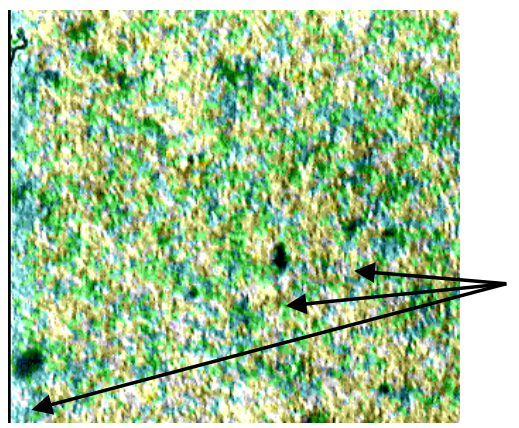

(e)

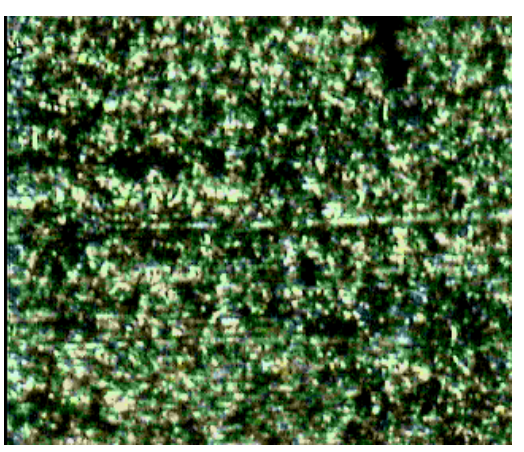

(b)

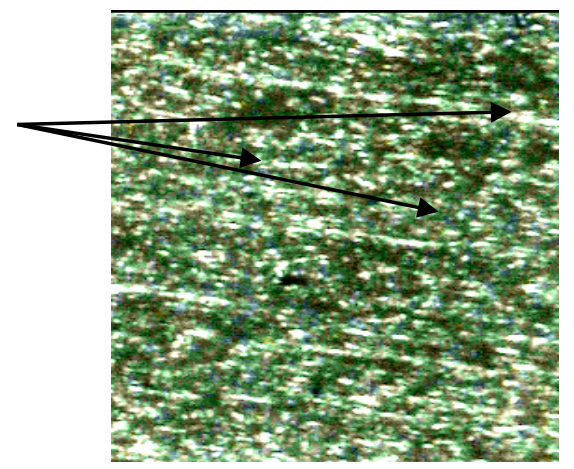

(d)

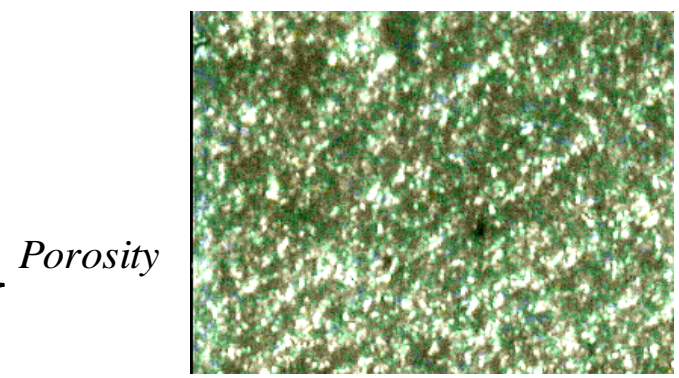

(f)

Figure 3 Comparing of Copper-Aluminum cross-sectional microstructure for different samples diameter. (a) $\mathrm{Cu} \varphi=1.75 \mathrm{~mm}$ (b) $\mathrm{Al} \varphi=3.16 \mathrm{~mm}$ (c) $\mathrm{Cu} \varphi=4.86 \mathrm{~mm}$ (d) $\mathrm{Al} \varphi=3.48 \mathrm{~mm}$ (e) $\mathrm{Cu} \varphi=8 \mathrm{~mm}$ (f) $\mathrm{Al} \varphi=8 \mathrm{~mm}$ ,X100. 
University of Thi-Qar Journal Vol.14 No.1 Mar 2019

Web Site: https://jutq.utq.edu.iq/index.php/main

Email: journal@jutq.utq.edu.iq

Porosity

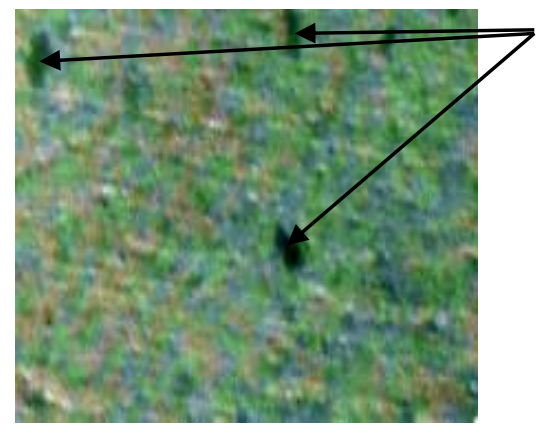

(a)

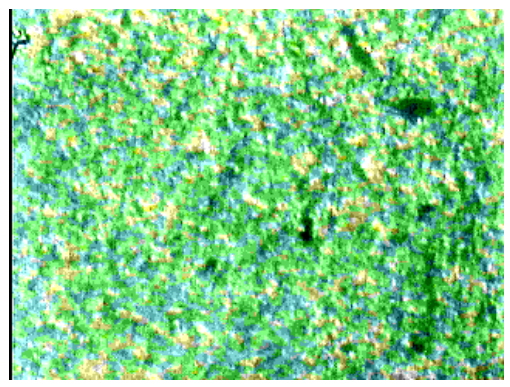

(c)

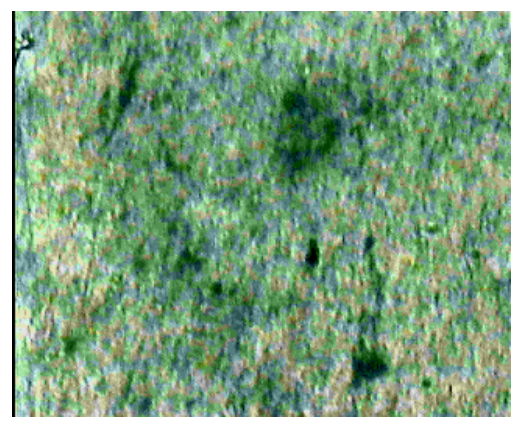

(e)

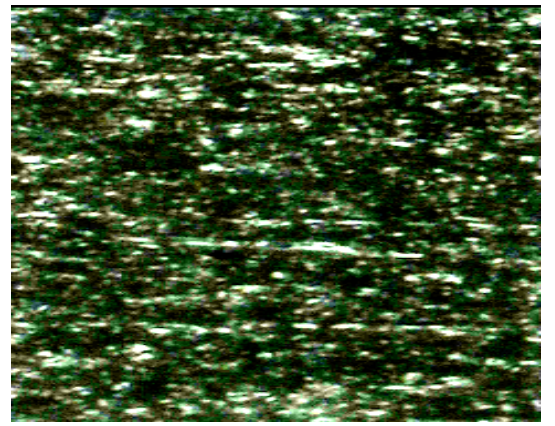

(b)

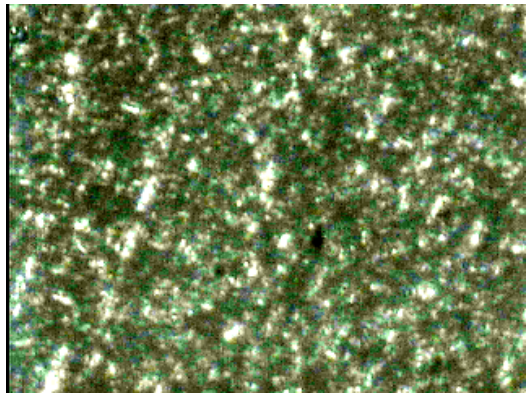

(d)

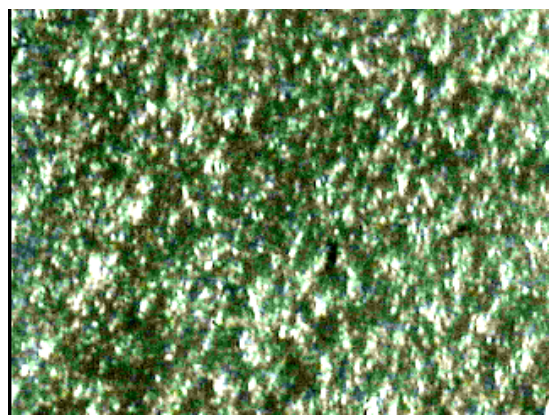

(f)

Figure 4 Comparing of Copper-Aluminum longitudinal microstructure for different samples diameter. (a) $\mathrm{Cu} \varphi=1.75 \mathrm{~mm} \quad$ (b) Al $\varphi=3.16 \mathrm{~mm}$ 
University of Thi-Qar Journal Vol.14 No.1 Mar 2019

Web Site: https://jutq.utq.edu.iq/index.php/main

Email: journal@jutq.utq.edu.iq

(c) $\mathrm{Cu} \varphi=4.86 \mathrm{~mm}$ (d) Al $\varphi=3.48 \mathrm{~mm}$ (e) $\mathrm{Cu} \varphi=8 \mathrm{~mm}$ (f) $\mathrm{Al} \varphi=8$ $\mathrm{mm}, \mathrm{X} 100$.
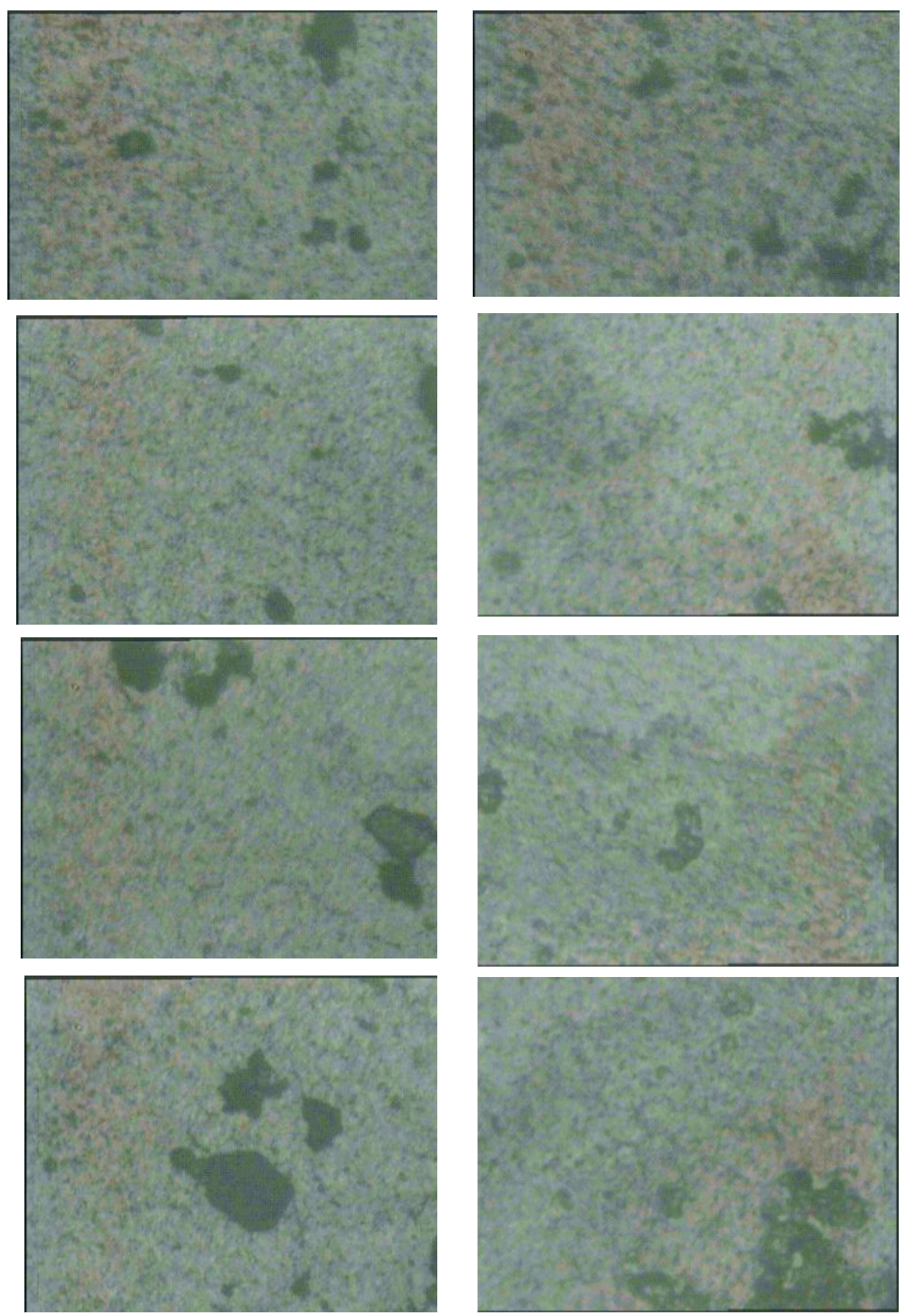


\section{University of Thi-Qar Journal Vol.14 No.1 Mar 2019}

Web Site: https://jutq.utq.edu.iq/index.php/main

Email: journal@jutq.utq.edu.iq

Figure 5 Porosity agglomeration which is producing wire failure at the drawing direction for copper wire, X100.
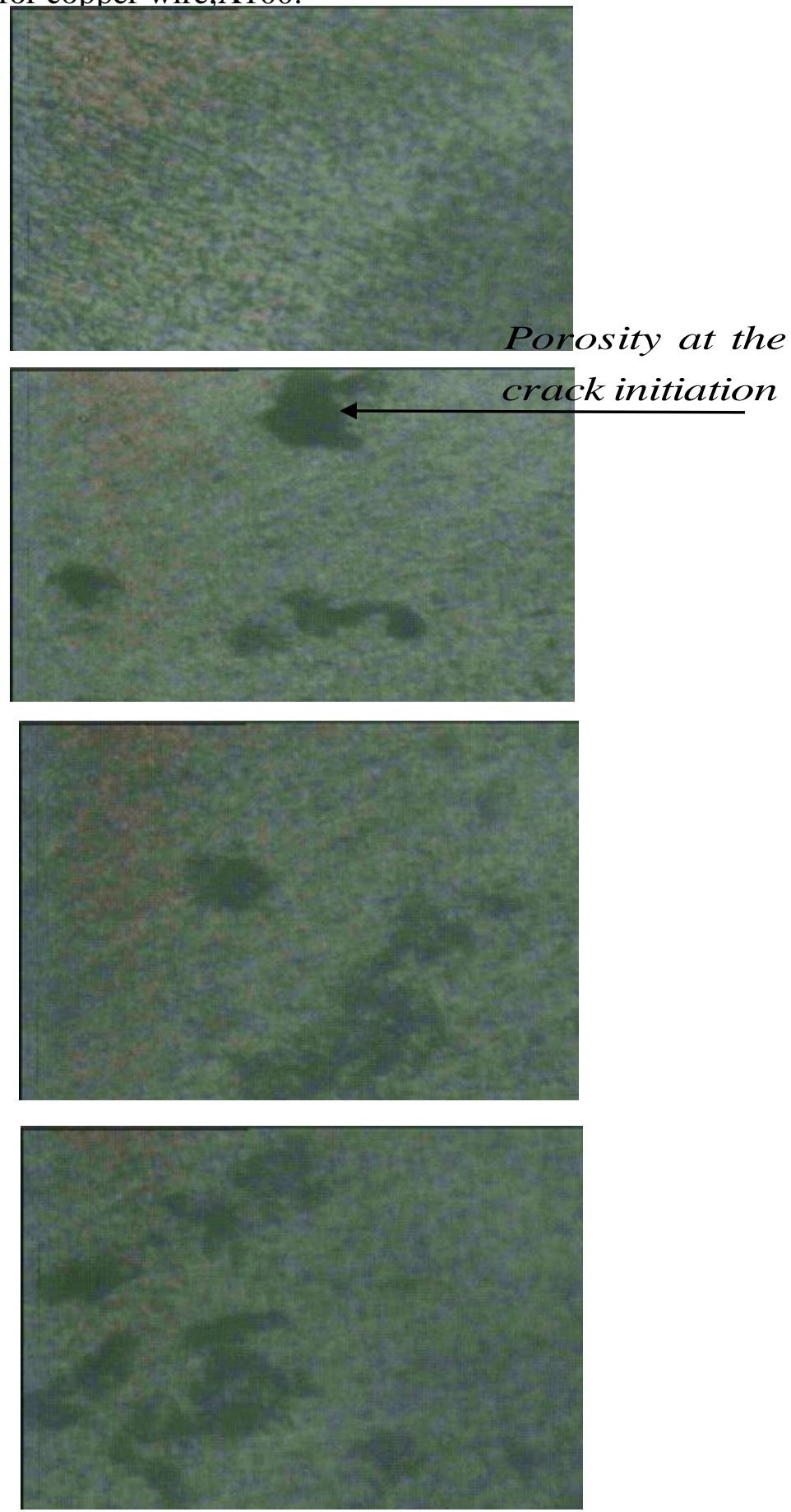


\section{University of Thi-Qar Journal Vol.14 No.1 Mar 2019 \\ Web Site: https://jutq.utq.edu.iq/index.php/main \\ Email: journal@jutq.utq.edu.iq}

Figure 6 Microstructure of failure wire in the cross sectional direction. Showing the porosity agglomeration at the final stage before cracking or wire distortion,X100.

\section{Conclusions}

Microstructure of failure wire demonstrates that the failure of wire drawing through different drawing stages results from the loss of its strength agents drawing stresses. This case came from the increase of heat due to drawing and reaching to recrystallization temperature which realize easy condition for accumulation defects like porosity. By progressing drawing the wire will fail due to the accumulation of these defects (porosity).

\section{References}

[1] ASMI, "Metals Handbook", Desk Edition, Second Edition, Printed by The Material Information Society, 1998.

[2] Sindo Kou, "Welding Metallurgy", Second Edition by Wiley, 2003.

[3] Gorden, P., Trans. AIME, 203:1043, 1955.

[4] Reed-Hill, R.E., "Physical Metallurgy Principles", Van Nostrand, New York, 1973.

[5] Burke, J.E., in "Grain Control in Industrial Metallurgy", ASM, Cleveland, OH, 1949. 